„Kwartalnik Filmowy” nr 111 (2020)

ISSN: 0452-9502 (Print) ISSN: 2719-2725 (Online)

https://doi.org/10.36744/kf.408

(c) Creative Commons BY-NC-ND 4.0

Magdalena Podsiadło-Kwiecień

Uniwersytet Jagielloński

https://orcid.org/0000-0003-3641-964X

\title{
Body/Ciało/Cielesność - o materii w filmach Małgorzaty Szumowskiej
}

\author{
Słowa kluczowe: \\ nowy materializm; \\ Małgorzata \\ Szumowska; \\ ciało; \\ cielesność; \\ materia
}

\begin{abstract}
Abstrakt
Jednym z głównych tematów w twórczości Małgorzaty Szumowskiej jest ciało ujęte w sposób podmiotowy, jako konstytutywny element tożsamości, oraz przedmiotowy, jako obiekt zabiegów medycznych, fragmentaryzacji, rozkładu, autopsji. Zwrócenie przez reżyserkę uwagi na materialność ciała oraz wskazanie splotu między nim a materią, która ma własną dynamikę i sprawczość, zachęca do przyjrzenia się jej wybranym dziełom z perspektywy nowego materializmu reprezentowanego m.in. przez Karen Barad, Rosi Braidotti czy Roberta Esposita.
\end{abstract}


Małgorzata Szumowska odnosiła pierwsze sukcesy międzynarodowe już jako studentka łódzkiej szkoły filmowej, a jej pełnometrażowy debiut Szczéśliwy człowiek (2000) przeszedł długą festiwalową drogę i był nominowany do Europejskiej Nagrody Filmowej. Prawdziwym wydarzeniem artystycznym stał się jednak dopiero jej trzeci film, 33 sceny z życia (2008), który zaskoczył nie tylko ostentacyjnym wręcz autobiografizmem (autorka dość długo się od niego odżegnywała), ale i bezlitosnym spojrzeniem na kwestie związane z wyniszczającą chorobą, śmiercią i degradacją ciała. Odtąd stałym obiektem zainteresowania reżyserki stało się ciało zarówno w jego wymiarze podmiotowym, stanowiąc konstytutywny element tożsamości, jak i przedmiotowym, jako obiekt zabiegów medycznych, fragmentaryzacji, rozkładu, sekcji zwłok. Szczególnie interesujące wydają się te filmy autorki, w których sposób ujmowania cielesności koresponduje z refleksją na temat ciała jako materii. Szumowska rezygnuje w nich wówczas z łączenia kwestii związanych z cielesnością z namysłem dotyczącym moralności. O ile w takich filmach, jak W imię... (2013) czy Sponsoring (2011) ciało zostaje uwikłane także w dyskurs erotyczny i etyczny, o tyle w Body/Ciało (2015), Twarzy (2017), 33 scenach z życia czy dokumencie A czego tu się bać? (2006) materia wysuwa się na plan pierwszy i nie jest podporządkowana skopofolicznej estetyzacji ani rozważaniom o moralności. W filmach tych istotniejszy staje się rozkład, wydalanie czy pochłanianie niż kwestie etyczne i dylematy grzeszącego ciała. Co istotne, mimo że reżyserka porusza we wspomnianych obrazach tematy związane ze śmiercią bądź umieraniem, unika w nich perspektywy metafizycznej, chyba że jest to - idąc za terminologią Jolanty Brach-Czainy - metafizyka mięsa, która nie kieruje myśli poza sam byt i jedynie naprowadza na to, w jaki sposób istniejemy ${ }^{1}$. Za sprawą powracających motywów związanych ze światem medycyny Szumowska zbliża się w wymienionych filmach raczej do nauk przyrodniczych, co odpowiada przesunięciu akcentów z teorii, które przyznaja prymat językowi czy społecznym konstruktom ${ }^{2}$, na teorie podkreślające twórczy charakter materii. Cechą łączącą wskazane filmy jest ponadto postrzeganie ciała, które podważa dualistyczny model świata, narusza granice między tym, co zewnętrzne i tym, co wewnętrzne, zespala to, co indywidualne z tym, co wspólno-

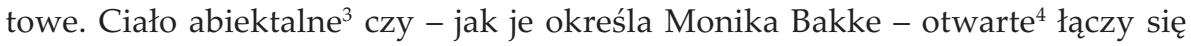
z materialną rzeczywistościa, a jednocześnie podlega przeobrażeniom za sprawą bodźców pochodzących z zewnątrz. Zwrócenie przez reżyserkę uwagi na materialność ciała oraz wskazanie splotu między nim a materia, która ma własną dynamikę i sprawczość, zachęca do przyjrzenia się jej wybranym dziełom z punktu widzenia nowego materializmu, reprezentowanego między innymi przez Karen Barad, Rosi Braidotti czy Roberta Esposita.

\section{$\mathrm{Z}$ powrotem do materii}

Należymy do świata - nie ma podziału na wewnątrz i zewnątrz ${ }^{5}$, głosi z perspektywy nowego materializmu Karen Barad. Badaczka uważa, że nie tylko należy traktować ciało jako twór społeczny, ale trzeba także uwzględnić jego materialny charakter. Nie odrzucając języka i kultury jako elementów odpowiedzialnych za konstrukcje tożsamości, autorka wskazuje na ich interakcje ze światem materialnym $^{6}$. Film Twarz Małgorzaty Szumowskiej - oparty na autentycznym zdarzeniu przeszczepu twarzy osobie, która uległa wypadkowi - podejmując kwestie doty- 
czące kształtowania się podmiotowości, przeczy zarówno twierdzeniu o sprowadzaniu jej do prostej ekspresji biologicznej natury, jak i traktowaniu jako wyłącznie społeczno-kulturowej konstrukcji ${ }^{7}$.

Twórczyni problematyzuje powyższy podział, czyniąc przeszczepioną twarz materialną podstawą modelowaną i kształtową przez medycynę i społeczno-kulturowe kody decydujące o tożsamości bohatera. Ta podwójna perspektywa została przez artystkę zaakcentowana już w filmie Body/Ciało, gdzie z jednej strony przedstawia ona ciało w całym jego fizjologicznym czy witalistycznym wymiarze, z drugiej zaś czyni je tematem reportaży telewizyjnych zrealizowanych podczas parad równości i procesji czy przedmiotem artykułów prasowych opisujących szokujące morderstwa. W Twarzy natomiast dochodzi do integracji porządku materialnego i społecznego, wówczas gdy po przeszczepie twarzy Jacek zaczyna być postrzegany jako sensacyjny przypadek medyczny, odmieniec lub monstrum. Zmianę tę w prymitywny esencjonalistyczny sposób tłumaczy matka bohatera, która zakłada, że z powodu transplantacji Jacek stał się kimś innym, potworem, „ryjem” - jak jest nazywany dla podkreślenia jego niesamowitego i wręcz nie-ludzkigo statusu - który przekaże swoim dzieciom genetyczną deformację ${ }^{8}$. Z kolei dziadek Jacka w dobroduszny, ale w gruncie rzeczy naiwny sposób zwraca się do wnuka: dla mnie nic się nie zmieniłeś, zakładając, że nowa twarz, jak tymczasowy kostium, nie ma wpływu na tożsamość bohatera. Zarazem jednak rychła śmierć najstarszego członka rodziny zrywa istotną więź łączącą bohatera z poprzednim wcieleniem.

Szumowska, nie rezygnując z ujmowania tożsamości jako konstruktu społeczno-kulturowego, czyni to poprzez cielesną materię, wskazując na jej sprawczość. Zazwyczaj ten rodzaj opowiadania mieści się raczej w ramach kina gatunkowego, gdzie zamiana skóry, za sprawa wypadku lub wspomagania technologicznego, zdaje sie prowadzić do poważnych reperkusji w tym, jak odczuwamy badź oceniamy nasza tożsamość Skóra - a tym bardziej twarz - jest znakiem indywidualności, pojedynczości i niepowtarzalności. Wyznacza granice naszego ,ja”, a wraz z jej ściągnięciem - jak dowodzi Teodora Manea, powołując się na analizowane przez siebie filmy - dochodzi do częściowej utraty tożsamości, ponieważ jej zamiana nie pozostaje obojętna dla konstruowania podmiotowości bohaterów. Nowa twarz stawia swoje własne żądania ${ }^{10}$, choćby te - jak w przypadku Jacka - dotyczące innego trybu życia, problematycznej sławy, zmierzenia się z biografią człowieka, od którego pochodzi, i z otaczającą go społecznością. Tym samym wskazywany przez Barad proces likwidacji granic pomiędzy tym, co osobowe i nie-osobowe, dyskursywne i materialne, został uwidoczniony za sprawą niecodziennego zdarzenia, którego doświadczył główny bohater. Oprócz zwrotu do materii jako do wspótkonstytuującego, aktywnego czynnika (...), który nie byłby wyłącznie pochodna ludzkiej intencjonalności ${ }^{11}$, dochodzi także do zakwestionowania uproszczonego dualizmu w postrzeganiu tożsamości, dzielącego ją na materię i niezależną od niej - w tym wypadku duchową - esencję ${ }^{12}$.

Szumowska, koncentrując się na ciele, odchodzi od tradycji zachodniego humanizmu, który umysł i ciało definiował rozłącznie, ze wskazaniem na intelekt jako ten, który stoi wyżej w hierarchii wartości. Model ten reprezentuje w filmie monstrualna, kilkunastometrowa żelbetonowa figura Chrystusa - ze wzrokiem odwróconym od okolicznych mieszkańców - która w tej formie staje się karykaturą chrześcijańskiej zasady prymatu ducha na materią. 
Reżyserka natomiast, wskazując na łączność i przechodniość między kategoriami umysłu i ciała, priorytetowo traktuje cielesność. Gigantyczną i odległą od ludzi figurę zastępuje wytatuowana na skórze Jacka głowa Jezusa i ciało „Dżizisa” (jak nazywany jest bohater) jako główny przedmiot refleksji. To, co duchowe nie może pominąć tego, co cielesne, o czym przypominają wytatuowane na ciałach symbole religijne czy narodowe (choćby znak Polski Walczącej na szyi jednego z bohaterów Body/Ciało). Taka korespondencja zachęca do biopolitycznej refleksji, która cielesność czyni punktem wyjścia dla namysłu politycznego, co stało się podstawą koncepcji immunizacji włoskiego filozofa Roberta Esposita.

\section{Immunizacja}

Wspomniane powyżej połączenie tego, co zewnętrzne (w tym wypadku ciało innego człowieka) z tym, co indywidualne odpowiada rozróżnieniu uczynionemu przez Maurice'a Merleau-Ponty'ego na tkankę cielesności świata i zindywidualizowane ludzkie ciało, które jest zrobione z tej samej tkanki cielesności, co świat ${ }^{13}$. Tym samym cielesność (flesh) decyduje o tym, że ciało (body) otwiera się na zewnętrzną wobec niego rzeczywistość i zawartą w nim samym różnicę.

Roberto Esposito, przyjmując założenie Merleau-Ponty'ego, głosi, że cielesność (flesh), czyli mięso to ciało, które (...) nie jest w petni ze soba zgodne, nie tworzy od samego początku organicznej jedności, wreszcie - nie wieńczy go głowa. (...) Zamiast tego mięso to nieforemna, różnorodna wielość, która może stanowić inspiracje dla projektu biopolityki afirmatywnej i jej punkt wyjścia ${ }^{14}$. Przynależność pojedynczego ciała do tkanki cielesności decyduje o jego zmienności, przekraczaniu granic, rozmyciu tożsamości. Esposito z refleksji nad ciałem i jego relacją wobec cielesności wyprowadza pojęcie immunizacji, odporności koniecznej do ochrony życia czy punktu oporu wobec tego, co wspólne. Termin immunizacja (...) nie ogranicza się już dziś do pierwotnych dziedzin medycyny i prawa, lecz obejmuje całość doświadczenia wspótczesności, zarówno rzeczywistego, jak $i$ symbolicznego ${ }^{15}$. W wymiarze społeczno-politycznym relacje między cielesnością a ciałem czy wspólnotą i jednostką opierają się na opozycji community (wspólnoty) i immunity (odporności). Wobec tych sił system immunologiczny jednostki musi zachować równowage - z jednej strony odporność jest konieczna do przetrwania, lecz zbyt daleko posunięta prowadzi do negacji życia (w języku medycznym: odrzucenia przeszczepu i śmierci), z drugiej strony brak oporu skutkuje wchłonięciem i utratą tożsamości (zniszczeniem organizmu przez komórki dawcy).

Podobnie jak w koncepcji Esposita, w której punkt wyjścia stanowi relacja między ciałem a cielesnościa, w filmie Szumowskiej opowieść o transplantacji twarzy jest zintegrowana z refleksją nad przynależnością do wspólnoty. Pojęcie immunizacji można interpretować wówczas dwojako - jako dotyczące samej społeczności przedstawionej w filmie będącej jednorodnym, homogenicznym środowiskiem, które ma trudność z absorbowaniem inności, oraz w odniesieniu do relacji bohatera ze wspólnotą. Samo pojęcie immunizacji koresponduje ponadto wprost z treścią filmu, czyli przeprowadzoną transplantacją twarzy. Przeszczep, pobudzając system immunologiczny bohatera, przynosi albo ryzyko odrzucenia organu dawcy, albo zniszczenia systemu odpornościowego gospodarza. Właściwa reakcja układu immunologicznego powinna pozwolić zachować równowagę mię- 
dzy tymi dwoma niepożądanymi efektami. Podobnie więc jak w biopolitycznej koncepcji Esposita, dyskurs medyczny staje się w filmie zaproszeniem do refleksji nad kwestią tożsamości oraz formującą ją przynależnością do wspólnoty.

Włoski filozof, analizując sposób kształtowania się wszelkich społeczności, wskazuje, że musiały one stawić czoło zagrożeniom ze strony środowiska naturalnego i innych ludzi, aby zagwarantować sobie przetrwanie ${ }^{16}$. Tak zdefiniowana odporność może prowadzić do stworzenia swego rodzaju pancerza, który przeradza się w karykaturę wspólnoty, czyli jednorodne, zamknięte ciało narodu, co znalazło swój skrajny wyraz w nazistowskiej polityce rasowej i ostatecznie doprowadziło tę hermetyczną społeczność do destrukcji. Na mniejsza, lokalną i nie tak radykalną skalę Szumowska przedstawia ten proces w swoim filmie. Przeszczep twarzy staje się cielesnym znakiem zanieczyszczenia prowincjalnego ciała przez rzeczywistość wobec niej zewnętrzna, która wymaga akceptacji inności. Owszem, Jacek jeszcze przed wypadkiem był outsiderem, jednak jego niezależność mieściła się w lokalnych normach, a nawet zapewniała mu swoistą popularność. Przeszczep nie tylko zmienia jego dotychczasową egzystencję, ale także wprowadza w życie jego i całej społeczności element obcy - twarz innego mężczyzny, cud medyczny, ogólnoeuropejską sławę, świat przyszłości znany tylko z opowieści science fiction o sztucznym człowieku bądź z opowieści grozy o szalonych naukowcach szyjących potwory z części martwego ciała. Owa inność zjawia się znienacka wśród mieszkańców, w znanym im chłopaku, w ich domu, przy odświętnym stole.

Jacek z przeszczepioną twarzą nieżyjącego już człowieka to owo wspomniane już ciało, które nie jest w pełni ze sobą zgodne ${ }^{17}$, co - jak się okazuje - decyduje o jego subwersywnym, wywrotowym charakterze. W ten sposób mięsność o której pisał Esposito - znosząc granice między jednostką a cielesnością, staje się antytotalitarna i antyautorytarna, ponieważ wymyka się mechanizmom zamknięcia i otwiera na "zewnętrze"18. Znajduje to swój wyraz w kontraście między „bezmięsną", kamienna, o jasno wyznaczonych granicach figurą Chrystusa (mającą swój prawdziwy odpowiednik w świebodzińskim monumencie) a niedomkniętym ciałem Jacka, opatrzonym tatuażem z wizerunkiem Jezusa. To, co niestałe, przelewające się, naruszające granice i tożsamości jest dla wspólnoty zbyt trudne do przyjęcia w przeciwieństwie do betonowego posągu Chrystusa.

Druga perspektywa odnosi się do losów samego Jacka, który musi zaakceptować swoją inność, zarówno tę fizyczna, jak i tożsamościową. W jego przypadku proces immunizacji polega na odporności na odmienność, którą system immunologiczny bohatera musi przyjąć i przeciwstawić się jej jedynie w ograniczonym zakresie. Obrona przed tym, co inne, czyli ciałem z obcego organizmu, oznaczałaby dla Jacka odrzucenie przeszczepu i śmierć. Jak pisze Esposito: Nadmiernie broniący się organizm ulega pokusie pozbycia się wszelkich ciat obcych, co ostatecznie staje się dla niego śmiertelnym zagrożeniem ${ }^{19}$. Tożsamościowa jednolitość i przynależność do prowincjonalnego ciała dla Jacka także oznaczałaby klęskę, skoro nosi w sobie pierwiastek buntu, niezależności i braku zgody na ograniczenia. Jego doświadczenie powinno stać się lekcją dla społeczności, w której bohater wzrastał, jednak tak się nie dzieje i w dalszej perspektywie możemy się spodziewać, że środowisko to pozostawi coraz mniej miejsca na różnorodność i wolność. 


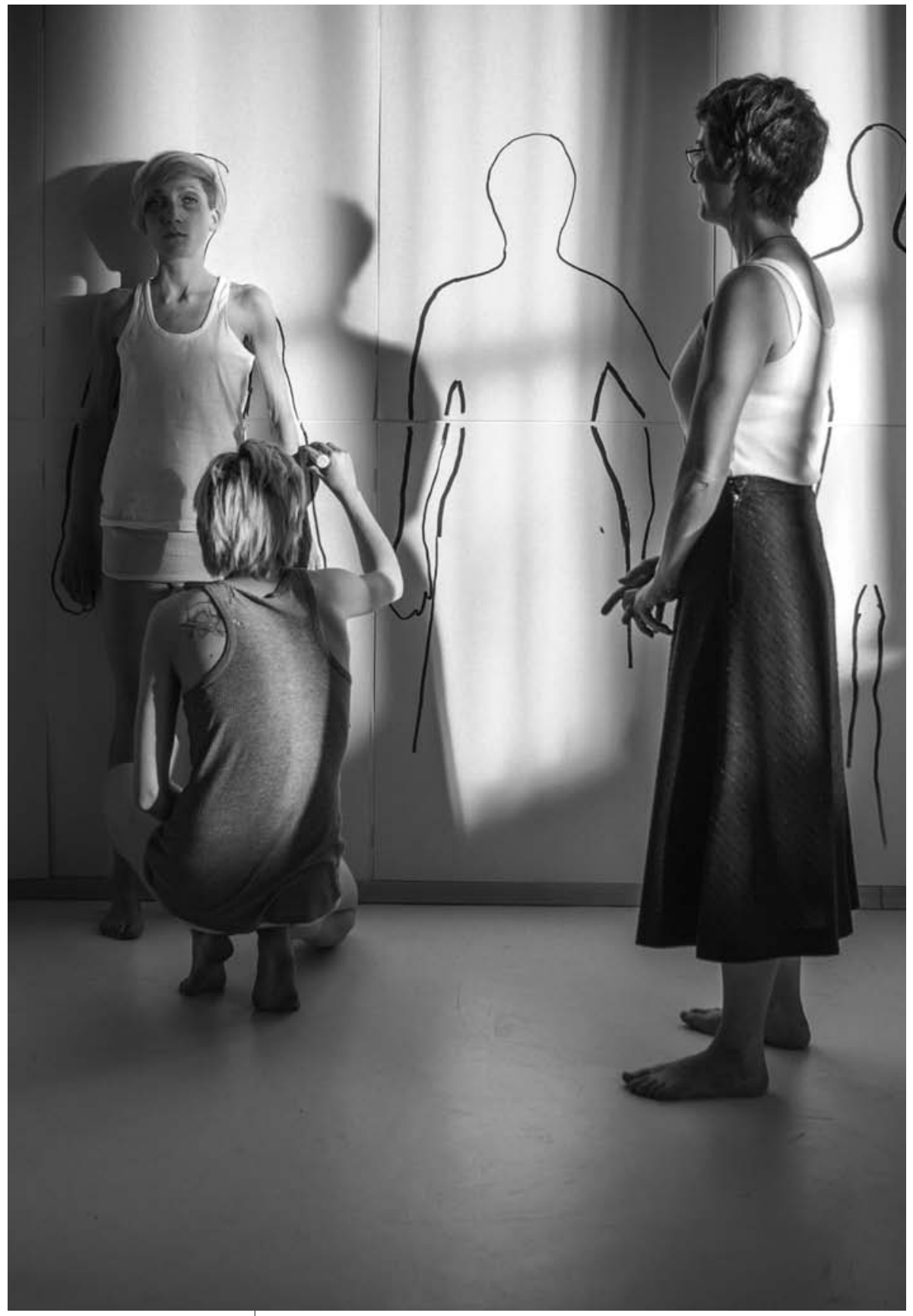

Body/Ciało, reż. Małgorzata Szumowska (2015) 


\section{Wszystko płynie}

Podaniu w wątpliwość dualizmu ciało-umysł oraz przerwaniu granicy między ciałem a cielesnością towarzyszy zakwestionowanie innych podziałów wywiedzionych z Kartezjańskiej idei rozumu. To on, dzieląc istnienia na rozumne i nie-rozumne, jest odpowiedzialny za wyrywanie nas ze wspólnoty, stanowiącej nasze miejsce ${ }^{20}$. Według Grega Garrarda proces ten prowadzi do podkreślania różnic między naturą a kultura, kobietą i mężczyzna, ciałem i dusza, tym, co irracjonalne i racjonalne, organiczne i nieorganiczne, ludzkie i nie-ludzkie ${ }^{21}$. Zakwestionowanie ostatniego z podziałów prowadzi do zatarcia granicy między tym, co przynależy do bios i stanowi indywidualne ludzkie istnienie a zoe, czyli wszelkim, bliżej nieokreślonym życiem² ${ }^{22}$, co znalazło swoją wykładnię między innymi w koncepcji nagiego życia Giorgia Agambena ${ }^{23}$. Już w filmie 33 sceny z życia, opartym na doświadczeniach reżyserki związanych ze śmiercią rodziców, bohaterowie mają wątpliwości, czy ojciec już „całkiem” nie żyje i czy można już o tym poinformować pozostałych bliskich. W podobnie ironiczny sposób Szumowska traktuje nieboszczyka w filmie Body/Ciało, gdy w scenie inicjalnej podczas prokuratorskiego rozpoznania zdjęty ze sznura wisielec wstaje i oddala się z miejsca oględzin ${ }^{24}$. Nie do końca jasna granica między tymi dwoma stanami wynika z przyznania materii swego rodzaju sprawczości. W filmie dokumentalnym A czego tu się bać? Szumowska wypytuje swoich rozmówców, których znajduje na mazurskiej wsi, o doświadczenie obcowania z martwym ciałem. W rozmowach tych ludzkie ciało nawet po śmierci zachowuje aktywność, na przykład współpracując z żywymi, którzy proszą je „po imieniu" o rozprostowanie nóg czy rąk. Nadal ma także wpływ na żywych przez wydzielanie trupiego jadu, który może przenieść się na otoczenie, czy za sprawą przynoszących śmierć spojrzeń niedomkniętych oczu. Owa wiara w sprawstwo materii przyjmuje wspomnianą już karykaturalną formę w filmie Twarz, wówczas gdy rodzina zakłada, że po przeszczepie, wraz z obcą tkanką w Jacka wstąpił demon, którego należy wypędzić z ciała za pomocą egzorcyzmów.

Szumowska sama jednak zwraca uwagę, że materia jest dynamiczna również po śmierci i na tym aspekcie się koncentruje. Swoje doświadczenie reporterskie związane z martwym człowiekiem relacjonuje w następujący sposób: I on się zmieniat. Z dnia na dzień inaczej te jego zwłoki wygladały, coraz młodziej przez pierwszy dzień, potem nagle zżótkt, takie dziwne miat fazy ${ }^{25}$. Podobnie opowiadają o śmierci bohaterowie wspomnianego dokumentu: zmarli cali pięknieja, brzydna, wzdymają się, ciekna, pękają i puchna, podlegając ciągłej zmianie. Aktywność i sprawstwo pojawiały się dotąd wyłącznie w różnych kontekstach osobowości-racjonalności, intencji, woli, autonomii ${ }^{26}$. Tymczasem, jak pisze Karen Barad, odczuwanie, pragnienie i doświadczanie nie sa cechami charakterystycznymi czy unikalnymi zdolnościami ludzkiej świadomości. Materia czuje, rozmawia, cierpi, pragnie, tęskni i pamięta ${ }^{27}$. Jej działanie w tym wypadku sprawia, że granica między ciałem żywych i martwych (?) staje się płynna. Ową materialną ciągłość podkreśla kontekst wizualny towarzyszący wypowiedziom bohaterów, czyli obrazy pól uprawnych, żniw, zaganianego bydła. Wydaje się, że w sekwencjach tych chodzi nie tyle o refleksyjność czy poszukiwanie transcendencji ukrytej za odwiecznym rytmem przyrody, ile o wpisanie istnienia ludzkiego w codzienną materialną rzeczywistość, której człowiek jest 
kontynuacją, a ona jego ciągiem dalszym. Szumowskiej zależy zresztą na tej konkretności i namacalności, wówczas gdy o śmierci opowiada, pokazując puchnące ciało, niedomykające się usta, rigor mortis, wytrzeszcz oczu czy stygnące ręce, a swoich rozmówców pyta raczej o ich stosunek do nieboszczyków niż do śmierci. Bliskość obcowania bohaterów z martwym ciałem polega na czuwaniu przy nim, myciu, ubieraniu, dotykaniu, ale też własnych przygotowaniach do tego stanu planowaniu ubioru czy wybieraniu rodzaju trumny. Szumowska w jednym z wywiadów z zachwytem cytuje powieściową historię z książki Michela Houellebecqa o obyczajach panujących na Madagaskarze i wykopywanych tam zwłokach, które uczestniczą jeszcze przez określony czas w życiu rodziny ${ }^{28}$. Człowiek jest tylko jednym z bytów pomiędzy nieokreślona liczba innych ${ }^{29}$, głosi z pozycji materialistycznej Karen Barad, a Rosi Braidotti podkreśla twórczy aspekt kontinuum życia i śmierci, zwracając uwagę na produktywny charakter zoe w odróżnieniu od indywidualnego bios. Autorka, kładąc nacisk na egalitarny w stosunku do wszystkich istnień charakter zoe, pisze: Nie zaprzeczam realności tego, co przerażające, chcę tylko przemieścić je tak, aby ukazać i utwierdzić moce uzdrowienia i współczucia ${ }^{30}$. Analogicznie czyni Szumowska, która nie uciekając od tematu śmierci, prezentuje jej fizyczna, zintegrowaną z rzeczywistością stronę.

Koncentracja na fizjologicznym i cielesnym aspekcie umierania koresponduje z rozumieniem, które wykracza poza podział na ciało i umysł, odsyłając tym samym do zmysłowo-afektywnych doświadczeń odbiorcy. Jak precyzuje Ryszard Nycz, zamiast klasycznego podmiotu racjonalnie zarządzającego soba, relacjami z innymi i ze światem, zjawia się jednostka o umyśle ucieleśnionym, która podziela wspólnotę z pozaludzkim światem ${ }^{31}$. Doznania afektywne, którym podlega, wykraczają poza racjonalne poznanie i są postrzegane jako nieświadoma, ukorzeniona w ciele i fizjologii intensywność, ucieleśnione doświadczenie, wysiłek rozumienia podmiotu poza podziałami na ciało i umyst ${ }^{32}$. Relacje bohaterów filmu Szumowskiej z jednej strony poddają fakt umierania konceptualizacji, z drugiej jednak wskazują na niepokojącą i trudną do symbolicznego uporządkowania styczność między teraźniejszym doświadczaniem własnej cielesności a myślą o pośmiertnym, lecz nieuchronnym, stawaniu-się-materią. Wrażenie to potęgują szczególnie te ujęcia, w których Szumowska prezentuje fotografie (być może przez siebie wykonane ${ }^{33}$ ) ułożonych na katafalku zwłok. To przede wszystkim w tych momentach widz doznaje afektywnego wstrząsu, prowokowany do rozpoznania siebie w nieznanym innym i w dzielonej z nim cielesności. Sceny te zachęcają do niemożliwego - usytuowania siebie w miejscu martwego ciała i wyjścia poza granice własnego ja.

Ta trudna do pojęcia a równocześnie obecna wspólnota staje się możliwa dzięki otwarciu widza na to, co wobec niego zewnętrzne, a jednak mu przynależne. Przywoływane wcześniej ciało abiektalne Kristevej znajduje swój odpowiednik w wizerunku zwłok, które wywołują gwałtowną reakcję repulsywną obserwatora z powodu wspomnianego nadwerężenia granicy między żywym i umarłym, tożsamym z sobą i otwartym. Trup - ogladany bez Boga i nie z perspektywy nauki - to szczyt wstrętu. To śmierć pustoszaca życie. Wy-miot. To odrzucony, od którego nie da się uwolnić, przed którym nie ma obrony, tak jak przed przedmiotem. Wyobrażona dziwność i realne zagrożenie; wzywa nas, a w końcu pochłania ${ }^{34}$ - pisze Kristeva. Konfrontacja widza z martwym ciałem i jego fizjologicznymi wydzielinami wywołuje uczucie wstrętu, które ma go „obronić” przed niepokojącym uczuciem utraty toż- 
samości i ponownie wyznaczyć naruszone granice. Intencją Szumowskiej było jednak „oswojenie” martwego ciała, stąd reakcja widza wobec niego może przebiegać od gwałtownego odrzucenia po częściowe z nim utożsamienie.

Tymczasem podobna materialna ciągłość między ciałem (body) a tym, co cielesne (flesh) pojawia się także w filmie Twarz, gdzie przeszczepiona tkanka należy do dwóch porządków: jest jednocześnie martwa - pochodzi od zmarłego, i żywa zostaje przyjęta przez biorcę. Z jednej strony twarz jest częścią ciała daleko zindywidualizowaną i osobnicza, z drugiej okazuje się organiczną materią, nad której mimiką bohater nie panuje, pobraną od nieżyjącego już człowieka i podtrzymywaną przy życiu za sprawą farmakologii dzięki postępowi medycyny. Ciało traci w tym wypadku swoją integralność, a reżyserka odchodzi od sztywnego podziału na to, co martwe i żywe, bierne i aktywne, indywidualne i materialne, zamknięte i otwarte, przynależne do ciała i jednocześnie od niego oddzielone. Jak pisze Ewa Domańska, wskazując na nekrosprawczość martwego ciała i jego szczątków (a tak można traktować twarz pochodzącą od innego człowieka), wyjście poza binarna opozycję w rozumieniu tego, co uważane jest za żywe i za martwe, [prowadzi] do sproblematyzowania pojęcia sprawczości ${ }^{35}$. Wówczas martwe ciała/szczątki oddziałują na rzeczywistość nie tylko pasywnie, dokonując zmian w świecie społeczno-kulturowym (dzięki interpretacjom i konceptualizacjom, jakim są poddawane), ale także aktywnie, bezpośrednio wpływając na inne osoby - jak choćby w przypadku Jacka - i środowisko.

\section{Ucieleśnienie sztuki}

Powracający w twórczości Szumowskiej motyw martwego ciała, rozkładu czy śmierci jest zatem droga, która łączy człowieka z dynamiczną materią. Jednocześnie stał się on pretekstem do zaprezentowania przez reżyserkę przedsięwziąć artystycznych, w których dochodzi do interakcji między fragmentami organicznymi a sztuką. Najpierw wątek ten pojawia się w filmie 33 sceny z życia, w którym bohaterka czyni z komórek nowotworowych matki temat swoich dzieł. Pod mikroskopem ogląda tkanki rakowe, a następnie wykorzystuje ich złożoną fakturę w swoich - dodajmy, niedocenionych - pracach. Relacje między sztuką a ciałem zawarte w 33 scenach z życia różnią się jednak diametralnie od tych przedstawionych w filmie Body/Ciało. Bohaterka tego pierwszego obrazu studiuje komórki rakowe pod mikroskopem i w ten sposób dystansuje się wobec choroby, oswajając ją w estetyczny i higieniczny sposób. W Body/Ciało natomiast pojawia się scena nawiązująca do życia i twórczości Zdzisława Beksińskiego. Główny bohater Janusz zostaje wezwany na miejsce zbrodni, której dokonano w mieszkaniu malarza. Obrazy przedstawiające monstrualne postacie zostają połączone z rozpryskami krwi i zwłokami ich twórcy, a to, co organiczne miesza się z nie-organicznym. Widać tu pewną analogię do fragmentu z książki Mapa i terytorium Michela Houellebecqa, którą twórczyni zna, o czym wspomina w wywiadzie z Agnieszką Wiśniewską ${ }^{36}$. Bohater powieści, introwertyczny Michel Houellebecq, zostaje brutalnie zamordowany w swojej posiadłości, a jego ciało rozczłonkowane. Zdjęcia z miejsca zbrodni przywodzą na myśl zaprzyjaźnionemu z nim malarzowi abstrakcyjne malarstwo Jacksona Pollocka i inspirację body artem. Tym samym to, co cielesne wykracza poza zamknięty podmiot w formie rozbryzgów krwi i rozrzuconych wnętrzności, łącząc się z otaczającą rzeczywistościa, w tym wypadku materią sztuki. 


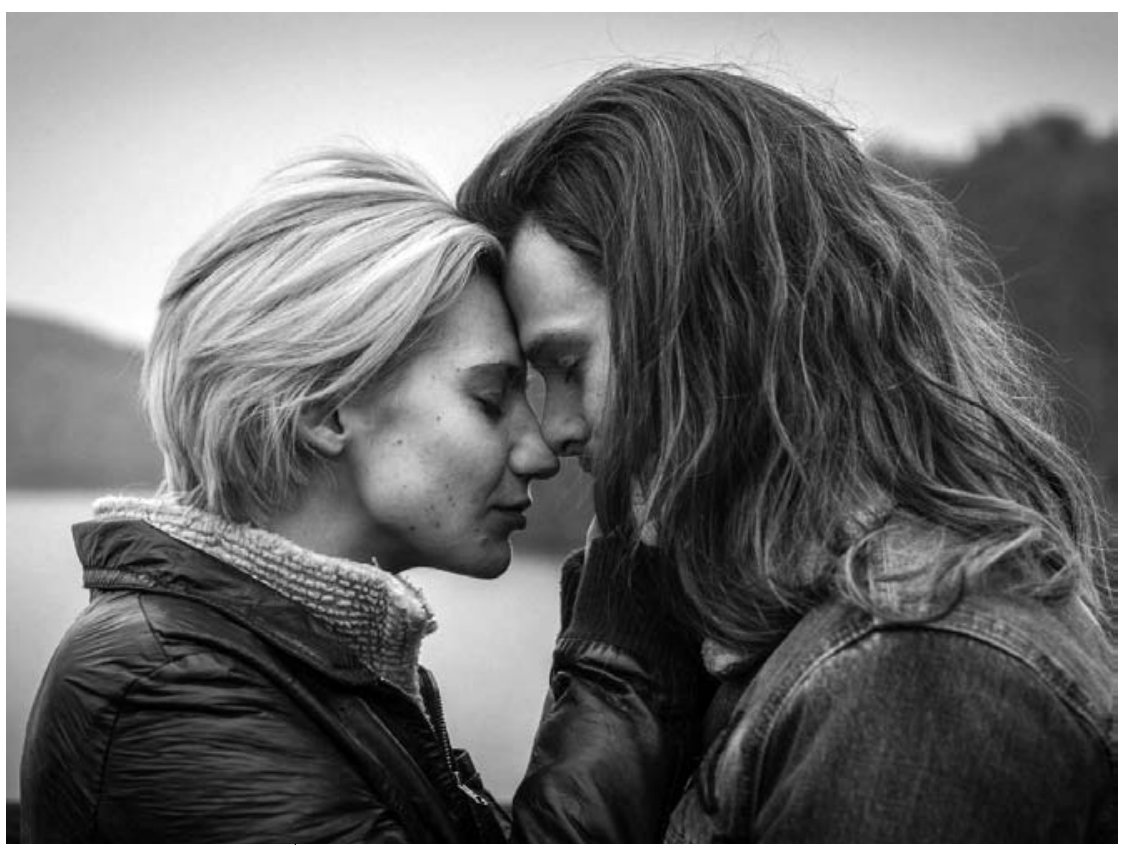

Tærarz, reż. Małgorzata Szumowska (2017)

Paradoksalnie wypowiedź ta jest bliższa bezkompromisowemu chwilami sposobowi ujmowania cielesności przez Szumowską niż sztuka tworzona przez Julię w ostentacyjnie autobiograficznych 33 scenach z życia - okiełznana, uporządkowana, poddana reżimowi medycznemu i estetycznemu.

\section{Przez dotyk}

O wspólnocie z tym, co krwawe, mięsne czy pośmiertne pisze Jolanta Brach-Czaina w słynnym eseju Szczeliny istnienia, postulując, że: Trzeba dotknać surowego mięsa. Trzymać je w ręku. Ściskać. Pozwolić, by przedostawało się między naszymi palcami. I trzeba dotknać palcami ciała zmarłego człowieka ${ }^{37}$. Bohaterowie $A$ czego tu się bać? opowiadają o ubieraniu, czesaniu, dotykaniu zwłok czy spaniu w ich obecności. Dla większości z nich taka współobecność jest powszechna i nie budzi ich lęku. Ten rodzaj obcowania ciała z ciałem Szumowska przedstawia także w filmie Body/Ciało, gdzie powódź wypłukuje trumny na cmentarzu, co rodzi konieczność identyfikacji pomieszanych przez żywioł zwłok. Matka, której straty nie mogą odżałować ani jej córka, ani mąż, nagle po latach nieobecności zjawia się w materialnej postaci. W częściowo odkrytej trumnie widzimy kobiece buty i suknię w burgundowym kolorze, których swojskość i zwyczajność czynią zwłoki bliskimi nam, a bohaterkę - fizycznie obecną wśród żywych.

Oprócz bliskości ze zwłokami Brach-Czaina wskazuje także na łączącą nas ze światem organiczną wspólnotę zasadzająca się przede wszystkim na dzielonej z nim mięsności i procesie wzajemnego pochłaniania. Co ciekawe, pisząc o otwarciu się na istnienie (w rozdziale zatytułowanym Otwarcie), autorka przywołuje rytuały przejścia pochodzące $\mathrm{z}$ Tybetu oraz towarzyszące tej ceremonii krzyki 


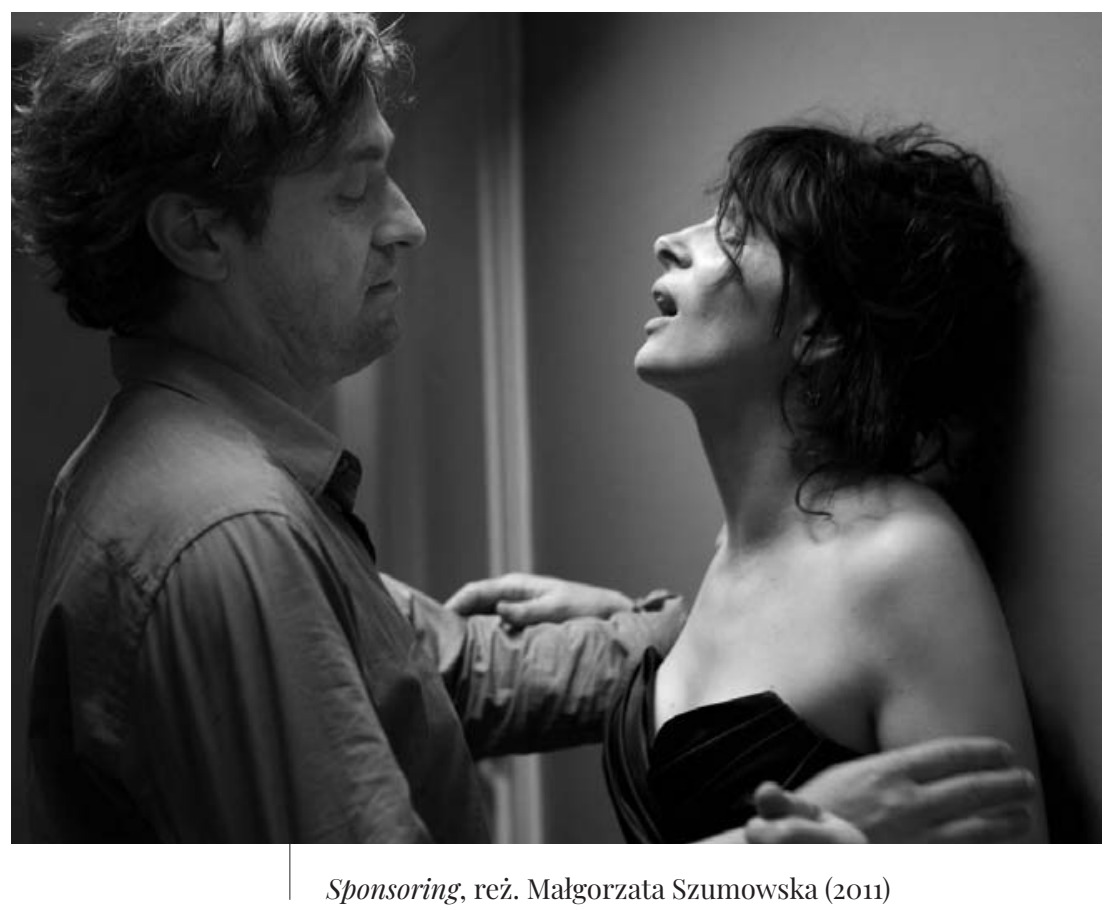

i trans ${ }^{38}$. W filmie Body/Ciało przyjaciółka Janusza także powołuje się na dalekowschodnią opowieść dotyczącą tybetańskiego mistrza, którego serce było po śmierci ciepłe, zaś ciało elastyczne, a on sam pozostawił po sobie jego trwały obrys. Obie historie opowiadają o wyjściu poza siebie i przekroczeniu monadycznego istnienia. Zarówno Brach-Czaina, jak i Szumowska przekonują jednak, że jest to możliwe także poza kulturą i filozofią Wschodu. Tuż po scenie rozmowy Janusza z przyjaciółką obserwujemy jej swego rodzaju trans i sławny już ekstatyczny taniec nago w rytm utworu Śmierć w bikini. Janusz oraz jego córka stanowią przeciwieństwo bohaterki (granej przez Ewę Dałkowską), czyli tego, co Brach-Czaina określa jako zmysłowe, dotykalne, bujne, triumfująco cielesne, czyli mięsne ${ }^{39}$. Tymczasem pozostali bohaterowie cierpią na deficyt cielesności, szczególnie widoczny w scenach terapii dla dziewcząt z zaburzeniami żywienia. Sylwetki bohaterek są niewyraźne, ledwo wyłaniają się z tła, co reżyserka podkreśla jasną kolorystyką kadrów i białymi strojami uczestniczek warszatów, podczas których dziewczęta zdobywają jednak wiedzę o sobie dzięki reakcjom ciała (krzyk, uderzenie) bądź wyrażają się w tańcu. Poznanie ma więc charakter ucieleśniony, zgodnie z zasada, że umyst nie jest czymś zlokalizowanym w całości w głowie ${ }^{40}$.

Zintegrowanie ciała i umysłu powoduje, że żałoba po matce i żonie skutkuje u bohaterów brakiem apetytu, wymiotowaniem bądź zabijaniem smaku. Jem, więc jestem $^{41}$, pisze natomiast Brach-Czaina, wskazując, że należymy do krwiożerczej wspólnoty, w której przyjmujemy pokarm lub nim jesteśmy, co oznacza, że wspólnota stworzeń rzadzi prawo pokarmu: pochłaniamy się wzajemnie, sami będąc nieodwołalnie skazani na pochłonięcie ${ }^{42}$, niezależnie od tego, czy jesteśmy ludźmi, czy nie-ludzkimi stworzeniami. Blisko tej myśli sytuuje się koncept Rosi Braidotti, która pisze o podmiocie relacyjnym, tzn. takim, który potrafi połączyć się z witalną siłą zoe $e^{43}$, czyli 
nieokiełznaną żywą materią. Odmawiająca jedzenia Olga zrywa związki ze światem, co jest aktem autoagresji ${ }^{44}$ potęgowanym przez kolejne próby samobójcze. Przezywany przez nią „Kulą” ojciec, mimo że wydaje się jej przeciwieństwem, ponieważ w każdych okolicznościach jest w stanie pochłonąć pokaźną ilość pokarmu, także jest swego rodzaju żywieniowym anorektykiem, skoro smak każdej potrawy zabija pieprzem, tak aby nie czuć go na podniebieniu. Owa wspólnota wymiany pokarmowej czy - jak pisze Brach-Czaina - wspólnota krwi, która polega na tym, że zachowane zostaje życie, gdy jakieś życie uchodzi (...) dzięki ofierze ostatecznej, która jest raczej pobierana, niż dobrowolnie składana przez ofiarującego się ${ }^{45}$, koresponduje także z Twarza Szumowskiej, gdzie dochodzi do dosłownego przekazania części ciała. Taka wymiana sprawia, że nasze istnienie nie jest absurdalne, skoro stanowimy mięso dla innych ${ }^{46}$. Tym samym mięsność jako ofiarowanie ciała zastępuje zdegradowany kult religijny, którego emanacją jest wspomniana już bezkrwista figura Chrystusa. Ciało zostało w niej pokonane - jak pisze Andrzej Marzec, przywołując przykład ciał-eksponatów, które są nieśmiertelne, ponadczasowe, niezmienne i doskonałe, jednak tym samym pozbawione wszelkiego życia ${ }^{47}$. Ich przeciwieństwem są ciała nieszczelne: zarówno te opisywane w dokumencie $A$ czego tu się bać? - gdy jedna z rozmówczyń mówi, że zdarzały się takie, gdzie leciało z każdej dziurki, jak i to należące do Jacka, absorbujące tkanki innego człowieka, czy ciało Olgi wstrząsane torsjami. Wypływające płyny ustrojowe, zwracanie pokarmu i przymusowe dożywianie uniemożliwiają wyznaczenie ciału klarownych granic i poddanie go pełnej kontroli, co według Julii Kristevej zaburza tożsamość, system, tad ${ }^{48}$.

\section{Bunt materii}

Odmowa jedzenia jest więc nie tylko rozłożonym na raty samobójstwem Olgi, ale także formą buntu wobec - jak się możemy domyśleć - tradycyjnego modelu społecznego, w którym jej matka doznała krzywdy. W momencie, gdy zastany porzadek jawi nam się jako źródło cierpień, jadło-wstręt wydaje się być jedynym wyrazem naszego sprzeciwu - a ciało miejscem opor $u^{49}$ - pisze Andrzej Marzec. Autor wskazuje, że dzieła, które manifestują ów opór, zwykle są poświęcone chorobie, starości i brzydocie, śmierci badź zwłokom, kalectwu czy przemocy seksualnej. Filmy Szumowskiej doskonale wpisują się w tę tematykę, co predestynowałoby je do miana subwersywnej sztuki wymiotnej ${ }^{50}$. Reżyserka nie jest może tak radykalna i dosadna w obrazowaniu wymieninych stanów, jak artyści wizualni, na których powołuje się autor, ale i u niej pojawiają się bezwzględne wizerunki wyniszczonego przez nowotwór ciała, wypadające pasmami włosy, zdjęcia nieboszczyków w różnym stadium rozkładu, odmawiające posłuszeństwa mięśnie twarzy czy powalanej wymiocinami bohaterki. W każdym z tych przypadków ciało ma potencjał wywrotowy i tak jak w historii Jacka czy Olgi staje się wyrazem niezgody na panujące wokół zasady społeczne. Naruszanie granic przez wydzieliny, organiczne resztki czy obecność martwych ciał służy destabilizacji symbolicznego porządku, którego emanacją jest stabilny podmiot, tradycyjny model rodziny czy społeczeństwa. Podważenie owych zasad sprzymierza się z szerszym spojrzeniem krytycznym, o którym wspomina Rosi Braidotti, z perspektywy materialistycznej poddając analizie światopogląd racjonalistyczny i sekularyzację. Jak wskazuje badaczka, świeckość jest fundamentem humanizmu, stąd wyjście poza niego odpowiada kondycji postsekularnej, do której 
odsyła między innymi film Body/Ciało. Sekularyzm stanowi, obok uniwersalizmu, jednolitego podmiotu oraz prymatu racjonalności, główna podstawę humanizmu ${ }^{51}$, więc jego kryzys doprowadził do triumfu nurtów postsekularnych. Postać Janusza w Body/Ciało reprezentuje światopogląd skrajnie racjonalistyczny i naukowy - jako prokurator opiera się on na dowodach, analizach, ekspertyzach, opiniach medycznych. Ten sam racjonalny światopogląd zawodzi go jednak wówczas, gdy traci żonę czy próbuje porozumieć się z nastoletnią córką. Kryzys wiary w aksjomaty świeckościs2 - rozumu i świeckiej racjonalności naukowej - znajduje swój wyraz w spirytyzmie Anny i postawie współpracującej z nią Olgi. Szumowska z ironią odnosi się do tych alternatywnych wobec rządów umysłu stanowisk, ale przypisuje im funkcję terapeutyczną i wskazuje, że światopogląd racjonalny oparty na silnej podmiotowości, humanizmie i sekularyzmie jest nieskuteczny w radzeniu sobie z bolesną rzeczywistością. Szydercze słowa konserwatywnego lekarza o przytulaniu drzew nie zaskarbiają mu sympatii widza ani nie zniechęcają do osoby Anny. Bohaterka dla siebie i dla swoich pacjentów znajduje pomoc wśród zmarłych, wsparcie u swojego czworonożnego przyjaciela czy w dalekowschodnich technikach terapeutycznych. Co ciekawe, film potwierdza także tezę Braidotti, że światopogląd irracjonalno-emocjonalny, stereotypowo i deprecjonująco przypisywany przez wieki kobietom, stał się ostatecznie podstawą światopoglądu postsekularnego, a ten paradoksalnie przysłużył się ich emancypacji. To z racjami kobiet sympatyzuje w filmie reżyserka, a wraz z nią także widzowie. Nawet jeśli z ironią spogląda na starania Anny, to jednocześnie nie po drodze jej z hierarchicznym modelem, którego zwieńczenie stanowi racjonalny, samostanowiący o sobie, wyizolowany i - jak mówi Braidotti - arogancki podmiot.

$$
\text { * * * }
$$

Skupienie się Małgorzaty Szumowskiej na materialności ciała pozwala na włączenie tego, co ludzkie w szerszy, materialny kontekst, a tym samym nie tylko wskazuje na przynależność człowieka do otaczającej go rzeczywistości, ale także poddaje antropocetryczny model krytycznej próbie, co jest nieodłączną częścią refleksji związanej z nowym materializmem. Nieszczelność granic między jednostką a tym, co wobec niej zewnętrzne, prowokuje do odmiennego ujęcia jej obecności w świecie i zachwiania tradycyjnych hierarchii. Z tej perspektywy człowiek podlega nie tylko zasadom wyznaczonym przez język bądź kulturę, ale także prawu produktywnej i sprawczej materii. Wówczas - jak głosi Braidotti - wyłania się z niego nowa wizja "ja": ucieleśnionego, rozszerzonego i relacyjnego ${ }^{53}$, które traci swoją przewagę w hierarchii bytów, ale jednocześnie zyskuje wśród nich nowe umiejscowienie.

${ }^{1}$ J. Brach-Czaina, Szczeliny istnienia, Wydawnictwo eFKa, Kraków 1999, s. 162.

${ }^{2}$ J. Bednarek, J. Maliński, Od redakcji, w: Nowy materializm. Wywiady $i$ kartografie, red. R. Dolphijn, I. van der Tuin, tłum. J. Czajka, A. Handke, J. Maliński, A. Marcisz, C. Rud- nicki, T. Wiśniewski, Fundacja Machina Myśli, Warszawa 2018, s. 5.

3 Zob. J. Kristeva, Potęga obrzydzenia. Esej o wstręcie, tłum. M. Falski, Wydawnictwo Uniwersytetu Jagiellońskiego, Kraków 2007, s. 10 . 
${ }^{4}$ Por. M. Bakke, Ciało otwarte. Filozoficzne reinterpretacje kulturowych wizji cielesności, Wydawnictwo Naukowe Instytutu Filozofii, Poznań 2000.

${ }^{5}$ E. Hyży, Dzielenie się światem. Nowy feministyczny realizm w ujecciu Karen Barad, w: Feministyczne konteksty. Multidyscyplinarnie, red. taż, Wydawnictwo Adam Marszałek, Toruń 2017.

${ }^{6}$ Zob. tamże, s. 60.

7 Tamże, s. 73.

${ }^{8}$ W filmie Bogowie (reż. Łukasz Palkowski, 2014), opowiadającym o działalności Zbigniewa Religi i transplantacjach serca, jedna z bohaterek także ma wątpliwości, czy po przeszczepie serca jej mąż nie stanie się innym człowiekiem.

${ }^{9}$ T. Manea, Our Posthuman Skin Condition, w: The Palgrave Handbook of Posthumanism in Film and Television, red. M. Hauskeller, C. D. Carbonell, T. D. Philbeck, Palgrave Macmillan, London 2015, s. 297.

${ }^{10}$ Tamże, s. 294.

${ }^{11}$ E. Hyży, dz. cyt., s. 59.

${ }^{12}$ Zob. T. Manea, dz. cyt., s. 294.

${ }^{13} \mathrm{M}$. Merleau-Ponty, Widzialne i niewidzialne, tłum. I. Lorenc, Fundacja Aletheia, Warszawa 1996, s. 247.

${ }^{14}$ T. Campbell, Immunizacja jako paradygmat nowoczesności. Z Robertem Espositem rozmawia Timothy Campbell, „Politeja” 2013, nr 23, s. 33.

15 Tamże, s. 31.

16 Zob. tamże.

${ }^{17}$ Zob. tamże, s. 33.

${ }^{18}$ M. Burzyk, P. Sawczyński, Wspólnota, immunizacja, życie - o filozofii politycznej Roberta Esposita, „Politeja” 2013, nr 23, s. 22.

${ }^{19}$ T. Campbell, dz. cyt., s. 35.

${ }^{20}$ J. Brach-Czaina, dz. cyt., s. 163.

${ }^{21}$ G. Garrard, Ecocriticism, Routledge, London - New York 2004, s. 25.

${ }^{22}$ Zob. M. Bakke, Bio-transfiguracje. Sztuka i estetyka posthumanizmu, Wydawnictwo Naukowe Uniwersytetu im. Adama Mickiewicza, Poznań 2010, s. 38.

${ }^{23} \mathrm{~W}$ Agambenowskiej interpretacji granica między zoe a bios zostaje zatarta, gdy mamy do czynienia z bios będacym swa własna zoe. Człowiek przeistacza się wówczas płynnie $\mathrm{w}$ to, co nieludzkie, czyli tzw. nagie życie, którego przejawy włoski filozof dostrzega w obozowym muzułmanie czy starożytnym homo sacer (zob. G. Agamben, Homo sacer, Suwerenna władza i nagie życie, tłum. M. Salwa, Prószyński i S-ka, Warszawa 2008, s. 256).
24 Zdarzenie to miało miejsce naprawdę, o czym Szumowska opowiada w jednym z wywiadów: K. Kubisiowa, Śmierć i co potem..., z M. Szumowską rozm. K. Kubisiowa, „Tygodnik Powszechny” 2015, nr 11, s. 54.

25 A. Wiśniewska, Szumowska. Kino to szkoła przetrwania, z M. Szumowską rozm. A. Wiśniewska, Wydawnictwo Krytyka Polityczna, Warszawa 2012, s. 144.

${ }^{26}$ R. Braidotti, Po człowieku, tłum. J. Bednarek, A. Kowalczyk, PWN, Warszawa 2014, s. 10.

${ }^{27}$ R. Dolphijn, I. van der Tuin, Wywiad z Karen Barad, tłum. J. Czajka, w: Nowy materializm. Wywiady i kartografie, dz. cyt., s. 50.

${ }^{28}$ A. Wiśniewska, dz. cyt., s. 143; por. M. Houellebecq, Mapa i terytorium, tłum. B. Geppert, W.A.B., Warszawa 2011, s. 47.

${ }^{29}$ E. Hyży, dz. cyt., s. 17.

${ }^{30}$ R. Braidotti, dz. cyt., s. 257.

31 Zob. R. Nycz, Afektywne manifesty, "Teksty Drugie" 2014, nr 1, s. 9.

${ }^{32}$ L. Nader, Afektywna historia sztuki, „Teksty Drugie" 2014, nr 1, s. 20.

${ }^{33}$ Fotografowanie zmarłych stanowiło punkt wyjścia dla dokumentu Małgorzaty Szumowskiej (A. Wiśniewska, dz. cyt., s. 143).

${ }^{34}$ J. Kristeva, dz. cyt., s. 10.

${ }^{35}$ E. Domańska, Nekros. Wprowadzenie do ontologii martwego ciała, Wydawnictwo Naukowe PWN, Warszawa 2017, s. 61.

${ }^{36}$ A. Wiśniewska, dz. cyt., s. 143.

${ }^{37}$ J. Brach-Czaina, dz. cyt., s. 163.

${ }^{38}$ Tamże, s. 23.

39 Tamże, s. 163.

${ }^{40} \mathrm{~J}$. Krueger, At Home in and Beyond Our Skin: Posthuman Embodiment inFilm and Television, w: The Palgrave Handbook... dz. cyt., s. 175.

${ }^{41}$ J. Brach-Czaina, dz. cyt., s. 171.

${ }^{42}$ Tamże, s. 168.

${ }^{43}$ R. Braidotti, dz. cyt., s. 120.

${ }^{44}$ J. Brach-Czaina, dz. cyt., s. 177.

${ }^{45}$ Tamże, s. 172-173.

${ }^{46}$ Tamże, s. 180.

${ }^{47}$ A. Marzec, Obrazoburcze ciało. Cielesność jako miejsce subwersji i oporu, w: (Nad)użycia ciała w kulturze, red. T. Rachwał, K. Więckowska, Wydawnictwo Naukowe UMK, Toruń 2012, s. 48 .

${ }^{48}$ J. Kristeva, dz. cyt., s. 10.

${ }^{49}$ A. Marzec, dz. cyt., s. 52.

50 Tamże, s. 54.

${ }^{51}$ R. Braidotti, dz. cyt., s. 91.

52 Tamże, s. 38.

53 Tamże, s. 188. 


\section{Magdalena \\ Podsiadło-Kwiecień}

Absolwentka polonistyki i filmoznawstwa na Uniwersytecie Jagiellońskim; adiunkt w Katedrze Historii Filmu Polskiego Instytutu Sztuk Audiowizualnych Uniwersytetu Jagiellońskiego. Autorka książki Autobiografizm filmowy jako ślad podmiotowej egzystencji (2013) i współredaktorka tomów Kino polskie jako kino transnarodowe (2017) oraz Przygoda kina (2019). Publikowała w „Kwartalniku Filmowym”, „Kulturze i Historii" oraz tomach zbiorowych.

\section{Bibliografia}

Bakke, M. (2000). Ciało otwarte. Filozoficzne reinterpretacje kulturowych wizji cielesności. Poznań: Wydawnictwo Naukowe Instytutu Filozofii.

Bakke, M. (2010). Bio-transfiguracje. Sztuka i estetyka posthumanizmu. Poznań: Wydawnictwo Naukowe Uniwersytetu im. Adama Mickiewicza.

Bednarek, J., Maliński, J. (2018). Od redakcji. W: R. Dolphijn, I. van der Tuin (red.), Nowy materializm. Wywiady i kartografie (wyd. 1, ss. 5-8). Gdańsk - Poznań - Warszawa: Fundacja Machina Myśli.

Brach-Czaina, J. (1999). Szczeliny istnienia. Kraków: Wydawnictwo eFKa.

Braidotti, R. (2014). Po człowieku (tłum. J. Bednarek, A. Kowalczyk). Warszawa: PWN. (Publikacja oryginału: 2013).

Burzyk, M., Sawczyński, P. (2013). Wspólnota, immunizacja, życie - o filozofii politycznej Roberta Esposita. Politeja, 23, ss. 5-27.

Campbell, T. (2013). Immunizacja jako paradygmat nowoczesności. Z Robertem Espositem rozmawia Timothy Campbell. Politeja, 23, ss. 29-39.

Dolphijn, R., van der Tuin, I. (2018). Rozdział 3. Wywiad z Karen Barad (thum. J. Czajka). W: R. Dolphijn, I. van der Tuin, Nowy materializm. Wywiady i kartografie (wyd. 1, ss. 41-58). Gdańsk - Poznań - Warszawa: Fundacja Machina Myśli.

Garrard, G. (2004). Ecocriticism. London - New York: Routledge.

Hyży, E. (2017). Dzielenie się światem. Nowy feministyczny realizm w ujęciu Karen Barad. W: E. Hyży (red.), Feministyczne konteksty. Multidyscyplinarnie (wyd. 1, ss. 57-79). Toruń: Wydawnictwo Adam Marszałek.

Kristeva, J. (2007). Potega obrzydzenia. Esej o zestręcie (thum. M. Falski). Kraków: Wydawnictwo Uniwersytetu Jagiellońskiego. (Publikacja oryginału: 1982).

Krueger, J. (2015). At Home in and Beyond Our Skin: Posthuman Embodiment in Film and Television. W: M. Hauskeller, C. D. Carbonell, T. D. Philbeck (red.), The Palgrave Handbook of Posthumanism in Film and Television (ss. 172-181). London: Palgrave Macmillan.

Kubisiowa, K. (2015). Śmierć i co potem... (z M. Szumowską rozm. K. Kubisiowa). Tygodnik Porszechny, 11, ss. 54-56.

Manea, T. (2015). Our Posthuman Skin Condition. W: M. Hauskeller, C. D. Carbonell, T. D. Philbeck (red.), The Palgrave Handbook of Posthumanism in Film and Television (ss. 289-298). London: Palgrave Macmillan. 
Marzec, A. (2012). Obrazoburcze ciało. Cielesność jako miejsce subwersji i oporu. W: T. Rachwał, K. Więckowska (red.), (Nad)użycia ciała w kulturze (ss. 47-64). Toruń: Wydawnictwo Naukowe UMK.

Merleau-Ponty, M. (1996). Widzialne i niewidzialne (thum. I. Lorenc). Warszawa: Fundacja Aletheia. (Publikacja oryginału: 1964).

Nader, L. (2014). Afektywna historia sztuki. Teksty Drugie, 1, ss. 14-40.

Nycz, R. (2014). Afektywne manifesty. Teksty Drugie, 1, ss. 9-13.

Wiśniewska, A. (2012). Szumozeska. Kino to szkoła przetrwania. Rozmazia Agnieszka Wiśnieroska. Warszawa: Wydawnictwo Krytyka Polityczna.

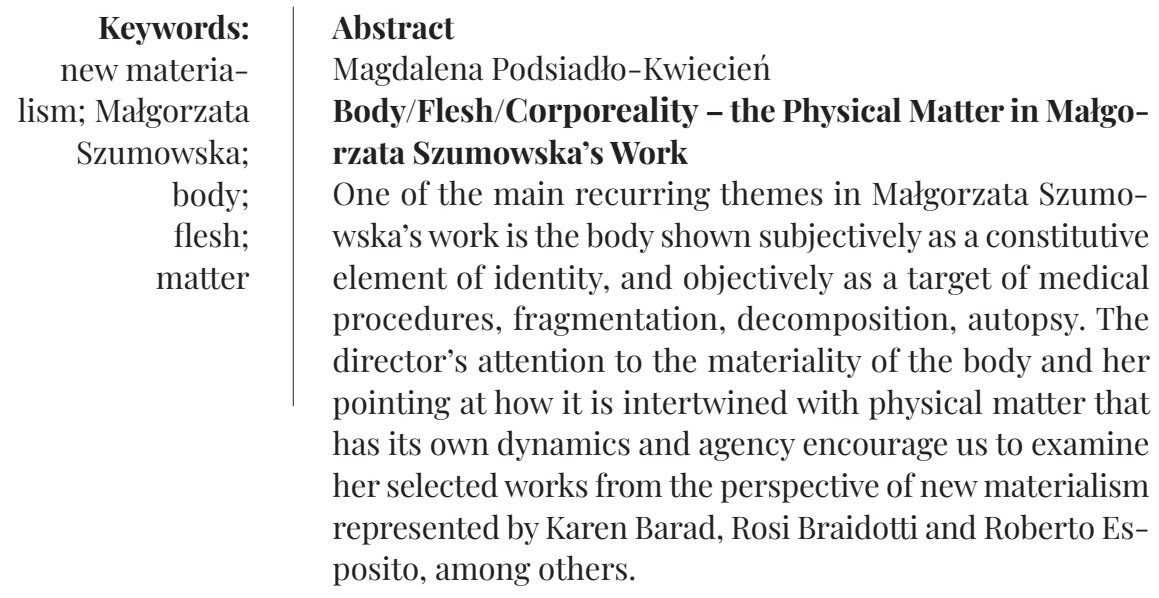

